\title{
Distribusi dan Pemetaan Varian-Varian Bahasa Sasak \\ di Kabupaten Dompu dan Bima
}

\section{Lukmanul Hakim $^{*}$}

\begin{abstract}
Abstrak
Adanya pemukiman-pemukiman Sasak dalam rentang waktu yang cukup lama di tengah-tengah komunitas Mbojo akan berdampak pada situasi kebahasaan pada kedua bahasa komunitas tersebut. Keadaan seperti itu akan menyebabkan kontak bahasa yang akan menimbulkan saling memengaruhi/saling meminjam satu sama lain. Variasi-variasi lingual akan menyebabkan perbedaan bahasa yang bersangkutan secara geografis dengan bahasa asalnya. Penelitian ini bertujuan membuat deskripsi yang lengkap tentang: variasi-variasi bahasa Sasak, hubungan kekerabatan antarvarian bahasa tersebut, dan sebaran geografisnya di Kabupaten Dompu dan Bima.
\end{abstract}

Kata kunci: varian-varian bahasa, dialektometri, kantong bahasa (enklave)

\section{Pengantar}

Penelitian terhadap daerah kantong bahasa di berbagai wilayah Indonesia perlu dilakukan mengingat pentingya dokumentasi lengkap atas berbagai bahasa dan sebaran geografisnya. Oleh karena itu, penelitian ini salah satu upaya melengkapi dokumentasi data bahasa yang sudah ada. Penelitian ini akan mengkaji salah satu daerah kantong bahasa yang ada di Kabupaten Dompu dan Bima, yaitu daerah kantong bahasa Sasak (BSas).

BSas merupakan salah satu bahasa daerah yang digunakan dan dilestarikan oleh masyarakat pemakainya yaitu suku Sasak, suku asli masyarakat yang bertempat tinggal di Pulau Lombok dan pulau-pulau kecil yang berada di sekitarnya. Di samping itu, ada juga di masyarakat

\footnotetext{
*) Sarjana Agama, Pembantu Pimpinan pada Kantor Bahasa Prov. NTB
} 
yang bertempat tinggal di daerah-daerah kantong transmigrasi, seperti di Pulau Sumbawa, Pulau Sulawesi, Pulau Kalimantan dan daerah-daerah lainnya. Jumlah penutur BSas di Provinsi Nusa Tenggara Barat 2.594.629 orang (Sensus Penduduk Tahun 2000). Apabila jumlah tersebut dikaitkan dengan pandangan Ferguson (dalam Abbas, 1983:1), hal itu berarti bahwa BSas termasuk bahasa mayor (major language) karena berpenutur lebih dari 1 juta orang.

Di wilayah Kabupaten Dompu dan Bima terdapat beberapa komunitas Sasak yang menggunakan BSas sebagai komunikasi sehariharinya terutama di lingkungan keluarga. Persebaran suku Sasak ke Kabupaten Dompu dan Bima disebabkan program transmigrasi. Menurut data terakhir dari Dinas Transmigrasi tahun 2005, terdapat dua belas komunitas Sasak di Kabupaten Dompu dan Bima yang sudah bermukim di atas 10 tahun, kebanyakan mereka berada di Kabupaten Dompu.

Adanya pemukiman-pemukiman Sasak dalam rentang waktu yang cukup lama di tengah-tengah komunitas Mbojo akan berdampak pada situasi kebahasaan pada kedua bahasa komunitas tersebut. Keadaan seperti itu akan menyebabkan kontak bahasa yang akan menimbulkan saling mempengaruhi/saling meminjam satu sama lain. Variasi-variasi lingual akan menyebabkan perbedaan bahasa yang bersangkutan secara geografis dengan bahasa asalnya. Dengan demikian, BSas di Kabupaten Dompu dan Bima akan secara lambat laun mengalami perubahan, baik dari segi fonologi, morfologi, maupun leksikon yang semakin membedakan dengan BSas di Pulau Lombok.

Metode yang digunakan dalam pengumpulan (penyediaan) data dalam penelitian ini adalah metode cakap dengan teknik cakap semuka, teknik catat dan teknik rekam. 
Kantor Bahasa Provinsi NTB

Instrumen yang digunakan sebagai pedoman wawancara adalah instrumen berupa daftar tanyaan yang sudah ditetapkan oleh Pusat Bahasa, yaitu berisi 200 kosakata swadesh, 880 kosakata budaya dan 41 daftar tanyaan berupa kalimat sederhana.

Desa-desa yang dijadikan sampel dipilih berdasarkan kriteria jarak antardesa, tingkat heterogenitas, dan ciri-ciri desa. Untuk jelasnya, desa-desa yang dipilih sebagai satuan pengamatan dapat dilihat pada tabelberikut ini.

Tabel 1 Daerah Pengamatan

\begin{tabular}{|l|l|c|c|}
\hline NO. & \multicolumn{1}{|c|}{ Nama Daerah Pengamatan } & Kabupaten & $\begin{array}{c}\text { Nomor Kode } \\
\text { dalam Peta }\end{array}$ \\
\hline 1. & $\begin{array}{l}\text { Desa So Nggajah, Kecamatan } \\
\text { Kempo }\end{array}$ & Dompu & 1 \\
\hline 2. & $\begin{array}{l}\text { Desa Lanci Jaya, Kecamatan } \\
\text { Manggalewa }\end{array}$ & Dompu & 2 \\
\hline 3. & Desa Woko, Kecamatan Pajo & Dompu & 3 \\
\hline 4. & Desa Taropo, Kecamatan Kilo & Dompu & 4 \\
\hline 5. & Desa Oi Saro, Kecamatan Sanggar & Bima & 5 \\
\hline
\end{tabular}

Selanjutnya, data yang diperoleh dianalisis yang berkaitan dengan analisis penentuan unsur-unsur bahasa yang berbeda, pemetaan unsurunsur bahasa yang berbeda tersebut, dan penentuan dialek BSas.

\section{Pembahasan}

\subsection{Deskripsi Perbedaan Linguistik dan Daerah Sebarannya}

\subsubsection{Perbedaan Fonologi}

\subsubsection{Korespondensi Vokal}

Korespondensi vokal yang berhasil diidentifikasi sebanyak 18 buah kasus, tetapi untuk keperluan ini hanya akan ditampilkan lima buah kasus sebagai contoh.

a. Pada silabe ultima dan penultima ditemukan korespondensi vokal: 
[â-â], yang digunakan pada daerah pengamatan: 1 dan 3;

[a-a], yang digunakan pada daerah pengamatan: 2;

[a-â], yang digunakan pada daerah pengamatan: 4 dan 5, seperti pada contoh berikut ini.

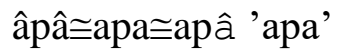

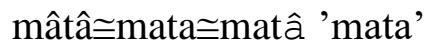

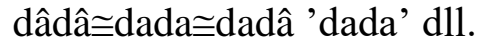

Makna 'mata' direalisaikan dengan bentuk yang tidak seetimon dengan bentuk yang berkorepondensi di atas, seperti penggunaan bentuk [p $\partial \mathrm{n} \partial \mathrm{nt} \partial \eta]$ untuk daerah pengamatan (1, 3 dan 4), dan bentuk

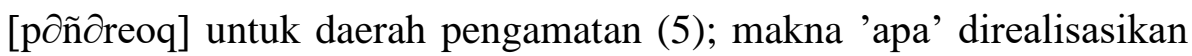
dengan bentuk [napi] untuk semua daerah pengamatan kecuali daerah pengamatan 2 .

b. Ditemukan korespondensi antara [e-i/u] dengan [â-i/u] dengan $[\mathrm{a}-\mathrm{i} / \mathrm{u}]$, pada contoh berikut ini.

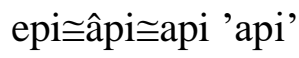

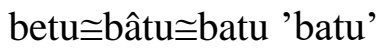

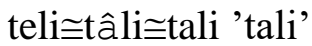

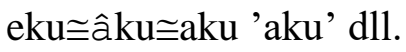

Patut ditambahkan bahwa bentuk-bentuk yang korespondensi tersebut masing-masing ditemukan pada daerah pakai yang berbeda. [e-i/u] digunakan pada daerah pengamatan 1 ;

[â-i/u] digunakan pada daerah pengamatan 3; dan [a-i/u] digunakan pada daerah pengamatan 2, 4, dan 5 .

Selain bentuk-bentuk yang berkorespondensi tersebut, untuk makna 'aku' direalisasikan dengan bentuk [tiaך] pada semua daerah pengamatan kecuali daerah pengamatan (2). 


\section{Kantor Bahasa Provinsi NTB}

c. Ditemukan korespondensi antara [i] dengan $[\varepsilon]$ pada posisi silabe ultima yang berakhir konsonan, seperti dalam data berikut ini.

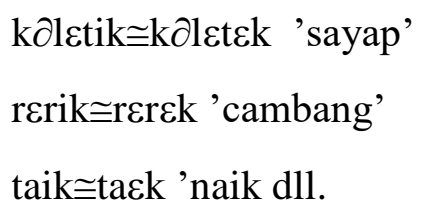

Patut ditambahkan bahwa bentuk-bentuk yang korespondensi tersebut masing-masing ditemukan pada daerah pakai yang berbeda. [i] digunakan pada daerah pengamatan 1, 2 dan 3; dan [ع] digunakan pada daerah pengamatan 4 dan 5

d. Korespondensi antara vokal [i] dengan [e] pada posisi awal, seperti dalam data berikut ini.

$$
\begin{aligned}
& \text { i(r,d)uperop 'hidup' }
\end{aligned}
$$

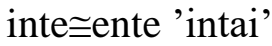

$$
\begin{aligned}
& \text { ijo@ejo 'hijau' dll }
\end{aligned}
$$

Bentuk yang menggunakan [i] dipakai oleh penutur yang mendiami daerah pengamatan (1-3) dan bentuk yang menggunakan [e] dipakai oleh penutur yang mendiami daerah pengamatan (4 dan 5).

Selain bentuk-bentuk yang berkorespondensi tersebut, makna 'hidup' direalisasikan dengan bentuk [urip] pada daerah pengamatan 3.

e. Korespondensi antara vokal $[\mathrm{U}]$ dengan $[\mathrm{u}]$ pada posisi silabe ultima yang berakhir konsonan dorsovelar, seperti dalam data berikut ini.

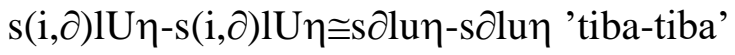

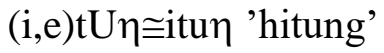

$\mathrm{d}(\mathrm{u}, \mathrm{o}) \mathrm{pUk} \cong \mathrm{dupuk}$ 'tumpul, dll 
Bentuk yang menggunakan [U] dipakai oleh penutur yang mendiami daerah pengamatan (1,3-5), dan bentuk yang menggunakan [u] dipakai oleh penutur yang mendiami daerah pengamatan (2).

Selain bentuk-bentuk yang berkorespondensi tersebut, untuk makna 'tiba-tiba' direalisasikan dengan bentuk [bârâ-bârâ] pada daerah pengamatan 1 dan 3; dan bentuk [barâ-barâ] pada daerah pengamatan 4 dan 5; makna 'hitung' direalisasikan dengan bentuk

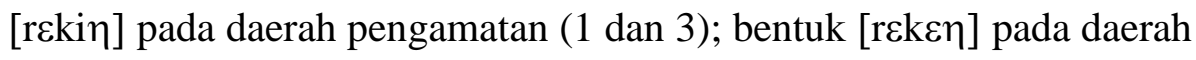
pengamatan (4 dan 5); makna 'tumpul' direalisasikan dengan bentuk [tupuq] pada semua daerah pengamatan.

\subsubsection{Variasi Vokal}

Variasi vokal yang berhasil diidentifikasi cukup banyak (sebanyak 47 buah kasus), tetapi untuk keperluan ini hanya akan ditampilkan lima buah kasus sebagai contoh berikut ini.

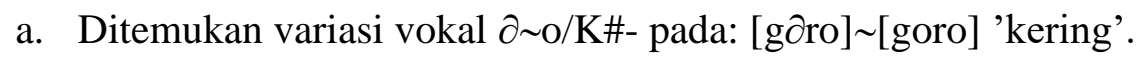

Daerah sebaran variasi vokal ini adalah:

$[\partial]$ terdapat di semua daerah pengamatan kecuali daerah pengamatan 2 yang menggunakan bentuk [o].

Selain bentuk tersebut, untuk merealisasikan makna itu juga

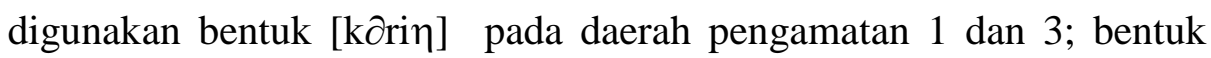

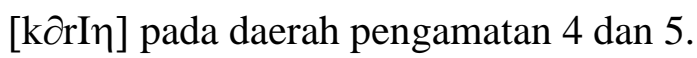

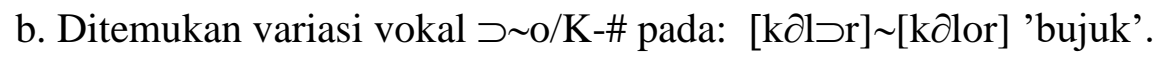

Daerah sebaran variasi vokal ini adalah:

[つ] pada daerah pengamatan: 1 dan 3; dan

[o] pada daerah pengamatan 4 dan 5

Selain bentuk tersebut, untuk merealisasikan makna itu juga digunakan bentuk [dahar] pada daerah pengamatan 3; bentuk [bədaran] 


\section{Kantor Bahasa Provinsi NTB}

pada daerah pengamatan 1, 4 dan 5; dan bentuk [manan] pada semua daerah pengamatan.

c. Ditemukan variasi vokal ei âi a ai pada:

[nei] [nâi] [nai] 'berak'.

Daerah sebaran variasi vokal tersebut adalah sebagai berikut.

[ie] pada daerah pengamatan: 1 ;

[âi] pada daerah pengamatan 3; dan

[ai] pada daerah pengamatan 2, 4 dan 5 .

d. Ditemukan variasi vokal i e/K\#- pada:

[tijoq] [tejoq] 'jari tunjuk'.

Daerah sebaran variasi vokal tersebut adalah sebagai berikut.

[i] pada daerah pengamatan 1 dan 3; dan

[e] pada daerah pengamatan 4 dan 5 .

Selain bentuk tersebut, untuk merealisasikan makna itu juga digunakan bentuk [jari tunjuk] pada daerah pengamatan 2 .

e. Ditemukan variasi vokal i-o $\sim \mathcal{E}-\supset \sim$ e-o pada :

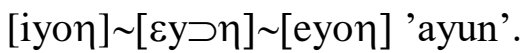

Daerah sebaran variasi vokal tersebut adalah sebagai berikut.

[i-o] pada daerah pengamatan: 1 dan 3;

[ $[$ ] pada daerah pengamatan 2; dan

[e-o] pada daerah pengamatan 4 dan 5 .

\subsubsection{Korespondensi Konsonan}

Perbedaan konsonan yang berupa korespondensi konsonan yang ditemukan dalam penelitian ini dapat dikemukakan berikut ini.

a. Korespondensi antara $\mathrm{h} \cong \mathrm{r} /-\#$, misalnya:

$[k \supset j \supset h] \cong[k \supset j \supset r]$ 'mati' 
$[1 \varepsilon m b a h] \cong[1 \varepsilon m b a r]$ 'pikul'

$[\mathrm{d} \partial \eta \mathrm{ah}] \cong[\mathrm{d} \partial \eta \partial \mathrm{r}]$ 'dengar' dll.

Daerah sebaran korespondensi konsonan di atas adalah:

[h] terdapat di semua daerah pengamatan kecuali daerah pengamatan 2 yang menggunakan bentuk [r].

Selain bentuk- bentuk yang berkorespondensi tersebut itu, juga digunakan bentuk-bentuk lain untuk merealisasikan makna-makna di atas. Untuk makna 'mati', direalisasikan dengan bentuk [mate] pada semua daerah pengamatan dan bentuk [p $\partial \mathrm{l} \supset \mathrm{t}]$ pada semua daerah pengamatan kecuali daerah pengamatan 2; makna 'pikul' direalisasikan dengan bentuk [pongoq] pada semua daerah pengamatan kecuali daerah pengamatan 2 .

b. Ditemukan korespondensi antara $\mathrm{n} \cong 1 /-\#$, misalnya:

$[\mathrm{t} \partial \mathrm{g} \partial \mathrm{n}] \cong[\mathrm{t} \partial \mathrm{g} \partial \mathrm{l}]$ 'pegang'

$[\operatorname{ad} \partial \mathrm{n}] \cong[\operatorname{ad} \partial \mathrm{l}]$ ' gusi'

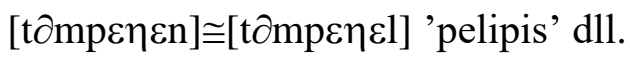

Daerah sebaran korespondensi konsonan di atas adalah:

[n] pada daerah pengamatan 1; dan

[1] pada daerah pengamatan: 2-5.

Selain bentuk-bentuk yang berkorespondensi tersebut itu, juga digunakan bentuk lain untuk merealisasikan makna-makna di atas, seperti penggunaan bentuk [d $\partial \mathrm{mak}]$ 'pegang' pada semua daerah pengamatan.

c. Ditemukan korespondensi konsonan $\mathrm{r} \cong \mathrm{d} / \mathrm{V}-\mathrm{V}$, misalnya:

[bir $\partial \eta] \cong[b(i, \varepsilon) d \partial \eta]$ 'hitam'

[ariq] $\cong[\operatorname{adik}]$ 'adik'

$[\operatorname{tir} \partial \mathrm{m}] \cong[\mathrm{t}(\mathrm{i}, \varepsilon) \mathrm{d} \partial \mathrm{m}]$ 'pejamkan mata' 


\section{Kantor Bahasa Provinsi NTB}

Daerah sebaran korespondensi konsonan di atas adalah:

[n] pada daerah pengamatan 1 dan 3; dan

[1] pada daerah pengamatan 2, 4 dan 5 .

Selain bentuk-bentuk yang berkorespondensi tersebut, untuk

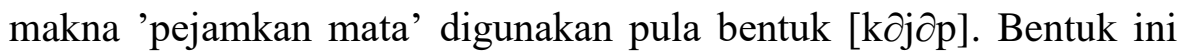
digunakan pada daerah pengamatan 2 .

\subsubsection{Variasi Konsonan}

Dari tiga puluh dua buah peta yang menunjukkan variasi konsonan hanya dipilih lima buah peta sebagai contoh yang dipaparkan dalam seksi ini. Untuk itu, akan diuraikan secara berturut-turut berikut ini.

a. Ditemukan variasi konsonan $\mathrm{h} \sim \mathrm{q} /-\#$ pada:

[bəlah] [bəlaq] 'membelah'.

Daerah sebaran variasi konsonan ini adalah:

[h] terdapat di semua daerah pengamatan kecuali daerah pengamatan 2 yang menggunakan bentuk [q].

Selain direalisasikan dengan bentuk tersebut, makna 'membelah' juga direalisasikan dengan bentuk [n $\supset \varepsilon q]$ yang digunakan pada semua daerah pengamatan kecuali daerah pengamatan 2 .

b. Ditemukan variasi konsonan k t n/\#- pada:

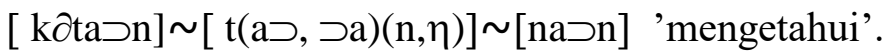

Daerah sebaran variasi konsonan ini adalah:

[k] terdapat pada daerah pengamatan 1 dan 3 , [t] terdapat pada daerah pengamatan 4 dan 2, dan [n] terdapat pada daerah pengamatan 5 .

c. Ditemukan variasi konsonan $\emptyset \sim \mathrm{r} / \mathrm{V}-\mathrm{V}$ pada bentuk: [uat] [urat] 'urat'.

Daerah sebaran variasi konsonan ini adalah: 
[Ø] terdapat di semua daerah pengamatan kecuali daerah pengamatan 2 yang menggunakan bentuk [r].

d. Ditemukan variasi konsonan $\mathrm{q} \sim \mathrm{h} \sim \varnothing / \#$ - pada: [suruq] [suruh] [suru] 'suruh'.

Daerah sebaran variasi konsonan tersebut adalah:

[q] pada daerah pengamatan 1, 3 dan 4;

[h] pada daerah pengamatan 5; dan

[Ø] pada daerah pengamatan 2 .

e. Ditemukan variasi konsonan $\mathrm{r} \sim \mathrm{d} / \#-$ pada:

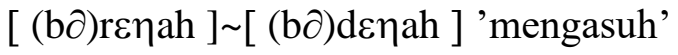

Daerah sebaran variasi konsonan ini adalah:

[r] pada daerah pengamatan 1 dan 3; dan

[d] pada daerah pengamatan 2, 4 dan 5 .

\subsubsection{Perbedaan Leksikon}

Berdasarkan data yang diperoleh dari penelitian di lapangan, ternyata perbedaan linguistik cukup banyak ditemukan dalam bidang leksikon (67 kasus), tetapi hanya sebagian saja yang akan dipaparkan dengan harapan dapat memberikan gambaran daerah sebaran perbedaanperbedaan secara menyeluruh.

Sehubungan dengan hal di atas, berikut ini akan dikemukakan beberapa perbedaan leksikon yang dimaksud seperti di bawah ini.

a. Makna 'dekat' memunculkan tiga varian: rap $\partial t$ yang digunakan pada semua daerah pengamatan; dekst yang digunakan pada semua daerah pengamatan kecuali daerah pengamatan 4; dan empah yang digunakan pada daerah pengamatan 5 .

b. Makna 'istri' memunculkan tiga varian: soninâ dan sobiniq yang digunakan pada semua daerah pengamatan kecuali daerah 


\section{Kantor Bahasa Provinsi NTB}

pengamatan 2; dan awa $\eta$ yang digunakan pada daerah pengamatan 2.

c. Makna 'kotor' memunculkan tiga varian yaitu: $r a \supset k$ yang digunakan pada daerah pengamatan 1, 3, dan 4; pila $\eta$ yang digunakan pada daerah pengamatan 2; dan garot yang digunakan pada daerah pengamatan 5 .

d. Makna 'lurus' memunculkan lima varian yaitu: topo $\partial \eta$ yang digunakan pada daerah pengamatan 1, 3, dan 4; bondor yang digunakan pada daerah pengamatan 1, 3, dan 4; lomboq yang digunakan pada daerah pengamatan 1 dan 2; papah yang digunakan pada daerah pengamatan 1,2 , dan 3; dan lつntah yang digunakan pada daerah pengamatan 5 .

e. Makna 'merah' memunculkan dua varian yaitu: $b \varepsilon a q$ yang digunakan pada semua daerah pengamatan kecuali daerah pengamatan 2 yang menggunakan aba .

\subsection{Penentuan Isolek Sebagai Dialek dan Subdialek}

Dalam bagian ini akan dilakukan penentuan isolek BSas di Kabupaten Dompu dan Bima sebagai dialek atau subdialek. Hal ini dilakukan agar diperoleh gambaran yang jelas mengenai hubungan antara isolek yang digunakan pada setiap daerah pengamatan. Untuk mencapai tujuan tersebut, langkah awal yang dilakukan adalah penerapan metode pemahaman timbal balik (mutual intelligibility). Hasil penerapan metode tersebut adalah diperolehnya gambaran bahwa semua daerah lokasi penelitian merupakan daerah-daerah pakai isolek yang dapat dikelompokkan dalam sebuah bahasa, yaitu BSas karena antarpenutur isolek yang berbeda itu masih terjadi pemahaman timbal balik satu sama 
lain ketika mereka bertutur dengan menggunakan isoleknya masing-masing. Hanya saja gambaran yang diperoleh dengan metode ini belum dapat mencerminkan daerah pemakaian isolek mana yang dapat disatukelompokkan dengan lainnya dan yang mana yang harus dikelompokkan ke dalam kelompok pemakaian isolek yang berlainan. Untuk itu, langkah selanjutnya adalah berupaya memperoleh kepastian pengelompokan pemakaian isolek yang dapat diverifikasi dan dipertanggungjawabkan. Dalam hal ini, dilakukan pengkajian dengan menggunakan metode dialektometri.

Berdasarkan hasil penghitungan secara kuantitatif dengan menggunakan metode dialektometri di atas diperoleh gambaran sementara bahwa daerah-daerah isolek Bsas di Kabupaten Dompu dan Bima terpilah dalam 2 kelompok, yaitu kelompok daerah pengamatan 1 dan 3 dengan dialek tersendiri, kelompok daerah pengamatan 4 dan 5 dengan dialek tersendiri pula dan kelompok daerah pengamatan 2 dengan dialek tersendiri bila dibandingkan dengan daerah pengamatan 1 dan 3; bila dibandingkan dengan daerah pengamatan 4 dan 5, daerah pengamatan 2 ini merupakan kelompok daerah pakai Bsas dengan bahasa yang berbeda dengan daerah-daerah pengamatan lainnya. Adanya simpulan daerah pengamatan 2 merupakan kelompok daerah pakai Bsas dengan bahasa tersendiri, padahal berdasarkan penerapan pertama diperoleh kesimpulan bahwa daerah pengamatan itu masih dalam kelompok daerah pakai Bsas. Perlu diterapkan metode yang lain yang dapat memasukkan daerah pengamatan itu dalam kelompok daerah pakai Bsas.

Metode selanjutnya yang diterapkan dalam rangka penentuan isolek sebagai dialek atau subdialek adalah metode dengan mengamati ciri lingusitik yang menjadi penanda dialek/subdialek yang telah 


\section{Kantor Bahasa Provinsi NTB}

ditentukan dengan melihat realisasi vokal [a] pada silabe ultima dan atau penultima dalam sebuah kata. Dalam merealisasikan ciri linguistik ini kelompok daerah pengamatan 1 dan 3 selalu merealisasikannya dengan pola â-â, daerah pengamatan 2 dengan pola a-a, dan kelompok daerah pengamatan 4 dan 5 dengan pola a-â. Dengan demikian, dapat dikatakan bahwa kelompok daerah-daerah isolek Bsas di kabupaten Dompu dan Bima terpilah dalam 3 kelompok, yaitu kelompok daerah pengamatan 1 dan 3, kelompok daerah pengamatan 2, dan kelompok daerah pengamatan 4 dan 5 .

Metode selanjutnya yang diterapkan untuk menguatkan kesimpulan metode di atas adalah metode inovasi bersama yang bersifat ekslusif. Berdasarkan penerapan metode ini diperoleh data-data sebagai berikut.

1. Data-data kualitatif yang menyatukan daerah pengamatan 1 dan 3 ke dalam satu kelompok dengan isolek tersendiri adalah data 1, 2, 6, 7, 8, 15, 17, dan 68 yang merupakan data korespondensi sangat sempurna; data $20,23,28,36,41,43,49,51,52,59,65,74,76,82$, dan 94 yang merupakan data variasi.

2. Data-data kualitatif yang menyatukan daerah pengamatan 4 dan 5 ke dalam satu kelompok dengan isolek tersendiri adalah data 1, 2, 5, 6, $8,9,10,11,12,14,15,16,17$, dan 18 yang merupakan data korespondensi sangat sempurna; data 20, 29, 31, 34, 36, 37, 38, 39, $40,41,42,43,45,49,51,52,59,61$, dan 65 yang merupakan data variasi; dan data 95 yang merupakan data leksikon.

3. Data-data kualitatif yang mengisolasi daerah pengamatan 2 dengan daerah-daerah pengamatan lainnya adalah $1,2,3,5,6,8,13,15,17$, dan 66 yang merupakan data korespondensi sangat sempurna; 19, 21, $22,26,27,28,29,30,32,34,35,36,38,39,41,43,46,49,50,51$, 
$53,54,57,58,60,62,64$, dan 65 yang merupakan data variasi; dan data $69,71,72,73,78,79,80,82,83,84,85,86,86,87,89,90,91$, 92, 93, 96, 98, 102, 103, 105, 106, 107, 110, 111, 112, 113, 114, $115,116,117,118,119,121,123,124,125,127,129,130,131,132$, $133,134,135,136,137,138,139,140,141,143,144,145,147,148$, $149,150,151,152,153,154,155,157,159,161,162,163,166$, dan 167 yang merupakan data leksikon.

Berdasarkan penerapan langkah-langkah di atas diperoleh gambaran bahwa BSas di Kabupaten Dompu dan Bima terpilah dalam tiga dialek, yaitu dialek Sasak Kempo (DSK) yang penuturnya sebagian besar menyebar di Desa So Nggajah Kecamatan Kempo dan Desa Woko Kecamatan Pajo Kabupaten Dompu, yaitu meliputi daerah pengamatan 1 dan 3; dialek Sasak Manggalewa (DSM) yang penuturnya sebagian besar menyebar di Desa Lanci Jaya Kecamatan Manggalewa Kabupaten Dompu, yaitu meliputi daerah pengamatan 2; dan dialek Sasak Sanggar (DSS) yang penuturnya sebagian besar menyebar di Desa Taropo Kecamatan Kecamatan Kilo Kabupaten Dompu dan Desa Oi Saro Kecamatan Sanggar Kabupaten Bima, yaitu meliputi daerah pengamatan 4 dan 5 .

Selanjutnya, berdasarkan hasil penghitungan metode dialektometri di atas diperoleh juga gambaran bahwa daerah pengamatan (4 dan 5) dan (1 dan 3) merupakan dua kelompok subdialek dari suatu dialek Bsas, tetapi dalam hal ini peneliti berpendapat bahwa kedua kelompok daerah pakai Bsas itu hanya merupakan dua kelompok pakai Bsas dengan dialek bahasa yang berbeda. Argumentasi yang dapat diajukan di sini adalah: 


\section{Kantor Bahasa Provinsi NTB}

1. adanya data-data kualitatif yang membedakan kedua kelompok daerah pengamatan tersebut berdasarkan penerapan metode inovasi bersama yang bersifat ekslusif;

2. dalam merealisaikan vokal [a] pada silabe ultima dan atau penultima dalam sebuah kata, kedua kelompok daerah pengamatan tersebut selalu merealisaikannya dengan realisasi yang berbeda; masingmasing kelompok merealisaikannya dengan pola â-â dan a-â (lihat data 1 korespondensi sangat sempurna).

Pembagian dialek BSas atas tiga buah tersebut juga didukung oleh pandangan para komparativis bahasa-bahasa Austronesia yang menyebutkan bahwa untuk kelompok bahasa-bahasa Austronesia Barat, vokal rendah, terbuka: [a] pada lingkungan silabe ultima merupakan vokal yang tidak stabil, dalam arti, pada isolek (bahasa-bahasa) turunannya cenderung muncul secara bervariatif. Oleh karena itu, penanda dialek dengan mengamati realisasi vokal tersebut pada lingkungan silabe ultima dan atau penultima cukup representatif. Dengan berpijak pada pandangan di atas, kiranya pembagian dialek BSas atas tiga buah berdasarkan langkah-langkah di atas bersesuaian dengan kemungkinan realisasi vokal rendah, terbuka: [a] pada lingkungan tersebut, sehingga secara linguistik, ketiga dialek BSas itu, masingmasing dapat pula disebut sebagai dialek [â-â] untuk dilaek Sasak Kempo, dialek [a-a] untuk dialek Sasak Manggalewa, dan dialek [a-â] untuk dialek Sasak Sanggar.

\subsection{Hubungan Kekerabatan Antarvarian}

Berdasarkan uraian sinkronis di atas diperoleh gambaran, bahwa BSas di Kabupaten Dompu dan Bima memiliki tiga dialek, yaitu dialek Sasak Kempo (DSK), dialek Sasak Manggalewa (DSM), dan dialek 
Sasak Sanggar (DSS). Secara kualitatif, hubungan kekerabatan di antara ketiganya dinyatakan dengan adanya hubungan dialek, yang meneruskan satu bahasa induk. Bahasa induk yang dimaksudkan adalah Prabahasa Sasak (PSas).

Ditinjau dari segi kedekatan antara dialek-dialek itu, dapat dikatakan bahwa pada fase historis tertentu DSK dan DSS diduga sebagai subdialek dari satu dialek. Dalam perkembangan BSas modern, kedua subdialek tersebut muncul sebagai dialek yang berdiri sendiri. Alasan yang dapat dikemukakan salah satunya adalah dengan mengamati korespondensi yang terdapat pada seksi 2.1.1.1 (butir a). Korespondensi ini memperlihatkan, ketiga dialek yang muncul dalam perkembangan BSas Modern tersebut ditandai oleh realisasi vokal [a] pada lingkungan silabe ultima dan penultima yang berbeda. Etimon bahasa purba (PAN/ B) *mata 'mata' direalisasikan oleh DSM sebagai [mata] 'mata', yang merupakan unsur retensi (penerusan tanpa perubahan), tetapi kedua dialek lainnya, DSK dan DSS, merefleksikan bentuk purba Austronesia itu dengan bentuk yang telah mengalami inovasi, masing-masing mâtâ dalam DSK dan [matâ] dalam DSS. Bentuk yang digunakan pada DSS merupakan hasil inovasi eksternal (pengaruh) dari bahasa Bali. Bentuk yang merupakan pengaruh bahasa Bali ini, secara geografis, keberadaannya tersebar merata di wilayah bagian barat Pulau Lombok. Hal ini sangat bersesuaian dengan fakta kekinian yang menunjukkan bahwa pengaruh Bali sangat kental berada di wilayah Lombok Barat. Adapun bentuk yang digunakan dalam DSK merupakan hasil inovasi internal, yang dilakukan oleh DSK, melalui proses asimilasi regresif bentuk yang terdapat pada DSS (DSS: matâ > DSK mâtâ (vokal [â] pada silabe ultima mempengaruh vokal [a] pada silabe penultima 


\section{Kantor Bahasa Provinsi NTB}

sehingga vokal tersebut berubah menjadi vokal yang sama dengan vokal pada lingkungan silabe ultimanya.

Dengan demikian, bentuk yang digunakan pada DSM merupakan bentuk yang lebih konservatif karena realisasinya sama dengan bentuk dalam bahasa purba Austronesia, sedangkan bentuk yang terdapat pada DSK dan DSS merupakan bentuk yang inovatif. Hanya saja, patut ditambahkan bahwa bentuk pada DSS lebih panjang sejarahnya dibandingkan dengan bentuk yang terdapat pada DSK. Bentuk pada DSK merupakan bentuk yang lebih modern. Oleh karena itu, pula dapat dirunut urut-urutan pembentukan bentuk-bentuk yang bersistem pada peta (1) tersebut sebagai berikut: PAN * mata > DSM mata > DSS matâ > DSK mâtâ dan lain-lain. Berdasarkan pada analogi urut-urutan pembentukan kata-kata di atas, dapat dikatakn bahwa bentuk yang bersistem [a-a] lebih tua sejarahnya dibandingakn dengan bentuk yang bersistem [a-â] dan [â-â], dalam pada itu bentuk yang bersistem [a-â] lebih panjang sejarahnya (lebih tua) dibandingkan dengan bentuk yang bersistem [â-â]. Mengingat kedua bentuk yang terakhir disebutkan di atas muncul dari hasil inovasi eksternal (pengaruh Bali) dan eksternal+internal, maka kenyataan itu berimplikasi historis bahwa pecahnya BSas ke dalam dialek-dialeknya itu diduga terjadi sebagai pengaruh dari kolonialisasi Kerajaan Karang Asem, Bali, (sekitar abad ke-18) atas Kerajaan Selaparang di Lombok. 
Berdasarkan pandangan historis itu pula, dapatlah disusun pohon kekerabatan BSas yang ada di Kabupaten Dompu dan Bima sebagai berikut.

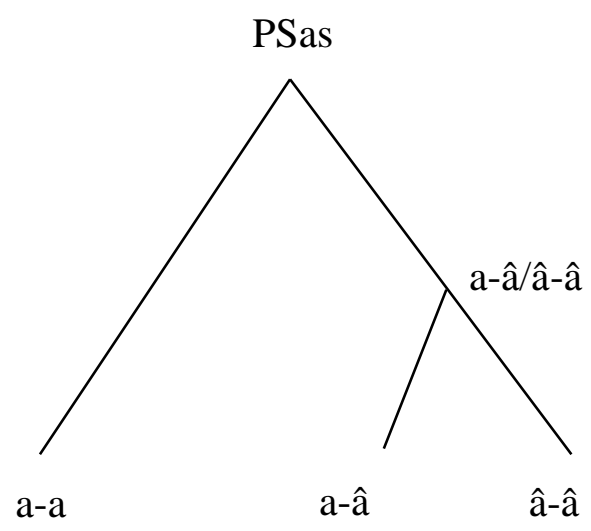

\section{Bagan 1 Pohon Kekerabatan Bsas di Dompu Bima}

Berdasarkan pohon kekerabatan BSas di atas, diperoleh gambaran bahwa dialek a-â lebih dekat hubungannya dengan dialek â-â, begitu pula sebaliknya, dengan dialek a-a. Hal ini didukung pula oleh hasil penghitungan hubungan kekerabatan dengan menggunakan metode dialektometri.

\section{Penutup}

\subsection{Simpulan}

Dari penelitian yang dilakukan terhadap BSas di Kabupaten Dompu dan Bima, dengan menggunakan pendekatan dialektologis, telah diperoleh 190 buah peta perbedaan unsur kebahasaan (fonologi dan leksikon), yang dikumpulkan pada 5 buah daerah pengamatan. Pembahasan terhadap 190 buah peta tersebut dilakukan secara sinkronis 


\section{Kantor Bahasa Provinsi NTB}

dan diakronis, yang hasil pembahasannya dapat dikemukakan sebagai kesimpulan berikut ini.

Secara sinkronis, pengelompokan daerah-daerah pengamatan yang bertetangga ke dalam daerah dialek atau subdialek didasarkan pada analisis pemahaman timbal balik, dialektometri, berkas isoglos, inovasi bersama yang bersifat ekslusif, dan realisasi vokal pada sialbe ultima dan/ atau penultima. Berdasarkan analisis tersebut terungkap bahwa BSas di Kabupaten Dompu dan Bima terbagi ke dalam tiga dialek, yaitu Dialek Sasak Kempo (DSK), Dialek Sasak Manggalewa (DSM), dan Dialek Sasak Sanggar (DSS).

DSK penuturnya sebagian besar menyebar di Desa So Nggajah, Kecamatan Manggalewa, Kabupaten Dompu dan Desa Woko, Kecamatan Pajo Kabupaten Dompu; DSM penuturnya sebagian besar menyebar di Desa Lanci Jaya, Kecamatan Manggalewa, Kabupaten Dompu; dan DSS penuturnya sebagian besar menyebar di Desa Taropo, Kecamatan Kilo, Kabupaten Dompu dan Desa Oi Saro, Kecamatan Sanggar, Kabupaten Bima.

Dengan mengamati korespodensi vokal pada struktur (v-v) ketiga dialek Bsas tersebut dapat juga disebut sebagai dialek (â-â) sebagai padanan DSK; dialek (a-a) sebagai padanan DSM dan dialek (a-â) sebagai padanan DSS, misalnya dapat dilihat pada bentuk yang menjadi realisasi makna 'suami', 'apa', 'dada', 'apa' dll.

Untuk makna 'apa', dalam ketiga dialek Bsas direalisasikan dengan bentuk yang berbeda secara fonologis. DSK merealisasikannya dengan bentuk âpâ; DSM: apa; dan DSS: apâ.

Secara diakronis, tingkat kedekatan antara dialek-dialek BSas memiliki perbedaan satu sama lain. DSK lebih dekat hubungannya dengan DSS, begitu pula sebaliknya, daripada dengan DSM. Dengan 
Mabasan 2007

demikian, dapat dikatakan bahwa pada fase historis tertentu DSK dan DSS diduga sebagai subdialek dari satu dialek. Dalam perkembangan BSas modern, kedua subdialek tersebut muncul sebagai dialek yang berdiri sendiri.

\subsection{Saran}

Penelitian tentang distribusi dan pemetaan varian-varian BSas di Kabupaten Dompu dan Bima dengan daerah pengamatan yang lebih luas pada masa yang akan datang perlu dilakukan. Hal ini untuk memberikan gambaran yang lebih jelas dan lebih lengkap mengenai situasi kebahasaan di Provinsi NTB pada umumnya, dan khususnya di Kabupaten Dompu dan Bima. 


\section{DAFTAR PUSTAKA}

Abas, H. 1983. Fungsionalisasi Bahasa Sebagai Norma Suprasional dan Bahasa Komunikasi Luas: Satuan Perspektif Sosiolinguistik untuk Tahun 2000-an. Ujungpandang: Universitas Hasanudin

Mahsun. 1995. Dialektologi Diakronis: Sebuah Pengantar. Yogyakarta: Gadjah Mada University Press

Badan Pusat Statistik. 2000. Penduduk Nusa Tenggara Barat, Hasil Sensus Penduduk Tahun 2000. Jakarta

Voegelin, C.F. dan Z.S Harris. 1951. "Method For Determining Intelligibility Among Dialects of Natural Language". Dalam Antrophological Philosopical Society-Proceeding. 95:3 